\title{
Pengembangan Stasiun Pusat RegionaL di Manggarai - Jakarta Selatan
}

\author{
Muhamad Agra Adhiprasasta dan Vincent Totok Noerwasito \\ Jurusan Arsitektur, Fakultas Teknik Sipil dan Perencanaan, Institut Teknologi Sepuluh Nopember (ITS) \\ e-mail:vtonoer@arch.its.ac.id
}

\begin{abstract}
Abstrak-Pemerintah DKI Jakarta berencana untuk merevitalisasi Transportasi umum di Jakarta, dan salah satunya ialah pembangunan jalur-jalur kereta baru. Diperlukan sebuah stasiun yang mampu mengakomodir jalur-jalur baru tersebut, dan salah satunya ialah dengan penetapan kawasan Manggarai sebagai Stasiun sentral regional. Yaitu stasiun yang melayani sarana transit antar jalur, dan sebagai titik pemberhentian kereta antar regional. Diperlukan sebuah metoda rancang yang mampu memenuhi kebutuhan pada stasiun dan pada lingkungan tersebut. Konsep yang terdapat pada stasiun adalah mengutamakan Waktu, Keamanan dan Kenyamanan bagi pengguna, dengan menciptakan sirkulasi yang efisien serta terintegrasi baik secara sistem dan fungsi bagi lingkungan, serta ruang yang memaksimalisasi fasilitas bagi seluruh penggunanya, dengan menciptakan sebuah stasiun yang mampu memaksimalkan efisiensi energi pada lingkungan, mengutamakan kenyamanan bagi setiap penggunanya, dan menjadi sebuah "Pintu Gerbang" Jakarta bagi orang orang daerah yang menuju Jakarta menggunakan kereta api.
\end{abstract}

Kata Kunci-Transportasi, Stasiun, Kereta, Transit, Regional.

\section{PENDAHULUAN}

$\mathrm{J}$ AKARTA, adalah sebuah ibukota Negara. Dengan luas area sekitar $661.5 \mathrm{~km}^{2}$, Jakarta menampung kurang lebih 12 juta jiwa pada siang hari, dan sekitar 9 juta jiwa pada malam hari. Menjadikan Jakarta merupakan salah satu kota terpadat di dunia.

Kurangnya fasilitas penunjang Transportasi Umum yang terdapat di kota Jakarta mengakibatkan terjadinya pengguna kendaraan pribadi yang membludak dibandingkan dengan pengguna kendaraan umum. Sehingga menciptakan sebuah permasalahan Transportasi yang cukup krusial didalam kota Jakarta. Salah satunya adalah kemacetan. Bilamana Jakarta tidak mampu merevitalisasi sistem Transportasi umum, maka diprediksikan Jakarta akan lumpuh total pada beberapa tahun yang akan datang. Salah satu Solusi Pemerintah DKI adalah dengan pembenahan sarana Transportasi yang sudah tersedia, yaitu Kereta api

Isu yang diangkat pada tugas akhir ini adalah mengenai pengembangan Stasiun Pusat yang berfungsi sebagai Stasiun antarkota maupun dalam kota, menurut RTRW (Rencana Tata Ruang Wilayah) Jakarta 2030, Stasiun Manggarai ditetapkan sebagai sebuah stasiun tersebut, yang berfungsi baik sebagai Stasiun Interchange dan sebagai Stasiun Regional antar kota-

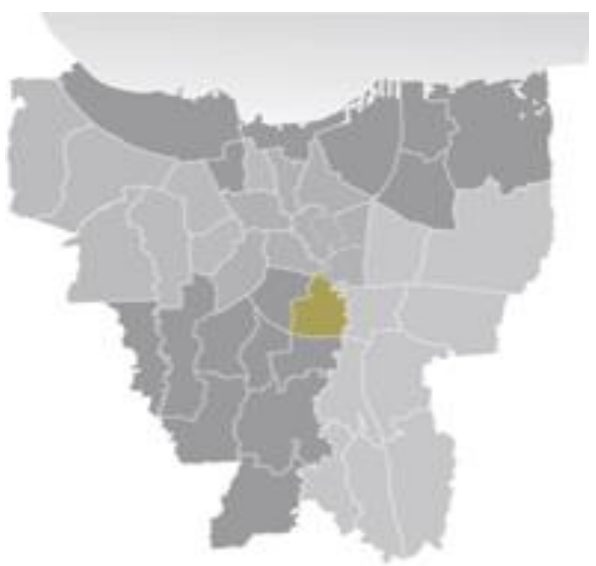

Gambar 1. Lokasi kawasan Manggarai yang berada pada kecamatan Tebet.

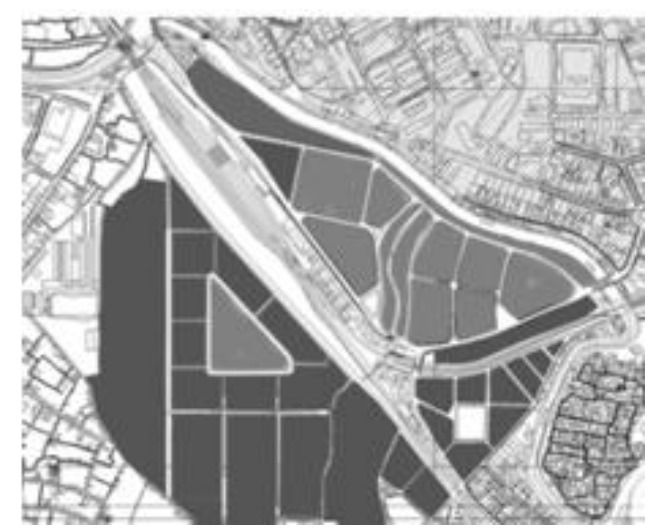

Gambar 2. Masterplan Kawasan Manggarai.

kota di pulau Jawa, guna memenuhi pelayanan terhadap jalurjalur kereta api yang baru.

Stasiun manggarai berlokasi pada Jl. Manggarai Utara 1, Kelurahan Manggarai, Kecamatan Tebet, Jakarta Selatan. Stasiun Manggarai adalah stasiun terbesar yang beroperasi di Jakarta saat ini. Stasiun ini dibangun oleh pemerintahan belanda untuk memenuhi kebutuhan transportasi baik untuk orang ataupun logistik. Ukuran tapak memiliki dimensi 190 x 130 meter dan luas 24.700 meter persegi

Pemilihan stasiun Manggarai sebagai Stasiun Sentral juga berdampak dengan pengembangan lingkungan pada lingkungan Stasiun yang akan menjadi sebuah TOD (Transit Oriented Development). Yaitu sebuah lokasi pengembangan tata ruang yang bersinergi dengan pembangunan transportasi, dalam kasus ini, terdapat stasiun kereta api serta terminal bus pada kawasan Manggarai. 


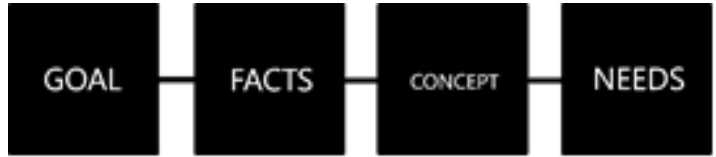

Gambar 3. Langkah Problem solving menurut Peña

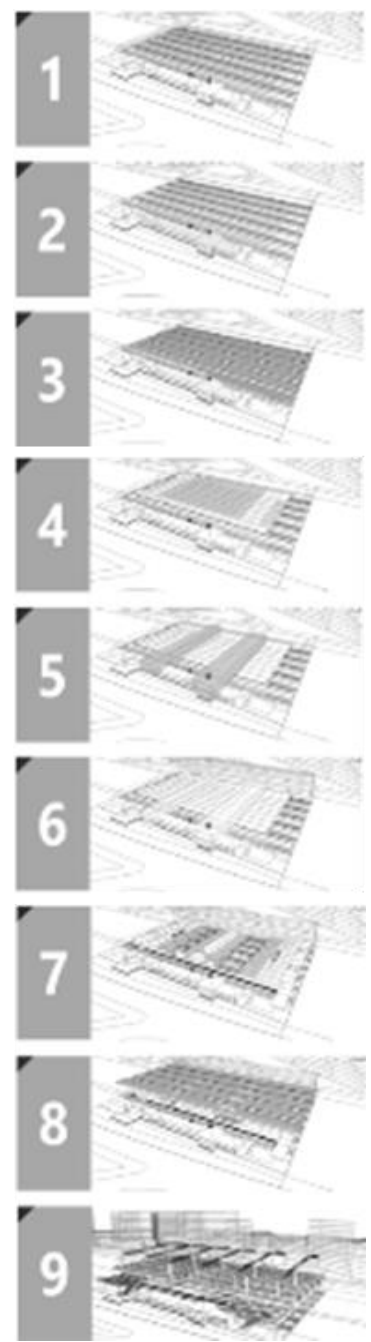

Gambar 4. Transformasi desain.

\section{METODA PERANCANGAN}

Untuk menciptakan sebuah desain yang mampu memanfaatkan iklim tropis pada lingkungan sekitar serta memberikan kenyamanan pada pengguna. Dengan itu melalui pendekatan Green Building diharapkan mampu meminimalis ir dampak negative yang diciptakan.

Pendekatan Green Building sendiri memiliki konsep pembangunan yang memperhatikan keseimbangan lingkungan alam dan buatan dengan unsur utama manusia, bangunan, dan lingkungan. Dimana manusia sebagai pelaku dan pengguna mempunyai keragaman sosial untuk mengolah bangunan dan lingkungan secara harmonis. Sehingga tercipta integrasi antara bangunan dengan lingkungan sekitar, Menurut GBCI (Green Business Certification Inc) pada salah satu program sertifikasinya yang bernama LEED (Leadership in Energy and Environmental Design), yang menjadi persyaratan bagi sebuah Green Building adalah:

1. Integrasi, yaitu bagaimana desain sebuah bangunan mampu berintegrasi dengan lingkungan sekitarnya.

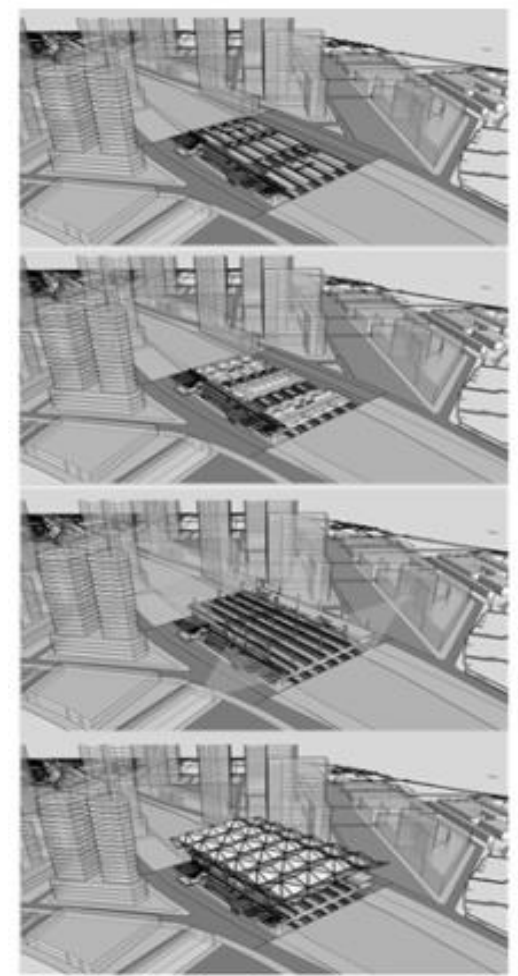

Gambar 5. Transformasi desain.
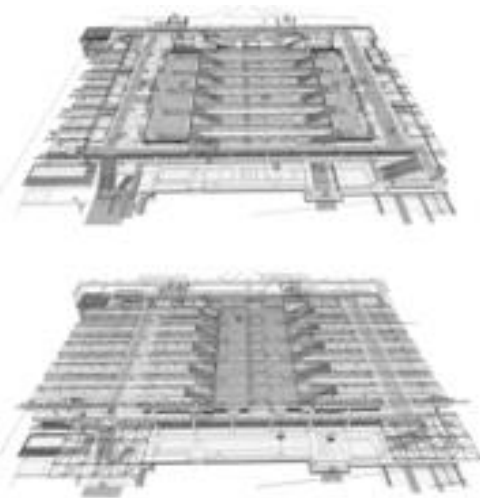

Gambar 6. Sirkulasi pada Stasiun.

2. Energi, yaitu bagaimana desain sebuah bangunan mampu menggunakan energi secara efisien dan memaksimalkan penggunaan energy tersebut.

3. Air, yaitu bagaimana desain sebuah bangunan mampu menggunakan air secara efisien, mengolah dan memaksimalkan penggunaan air tersebut.

4. Limbah, bagaimana sebuah desain bangunan mampu mengelolah limbah yang diciptakannya.

5. Material, bagaimana penggunaan material yang berada dekat dengan lokasi dan material tersebut ramah terhadap lingkungan.

6. Lokasi \& Transportasi, bagaimana letak bangunan tersebut sangat berdekatan dengan sistemtransportasi.

7. Kesehatan \& Pengalaman Manusia, yaitu bagaimana desain interior bangunan yang mampu memberikan kenyamanan bagi penggunanya, baik dari hawa, cahaya, dan lain-lain. 


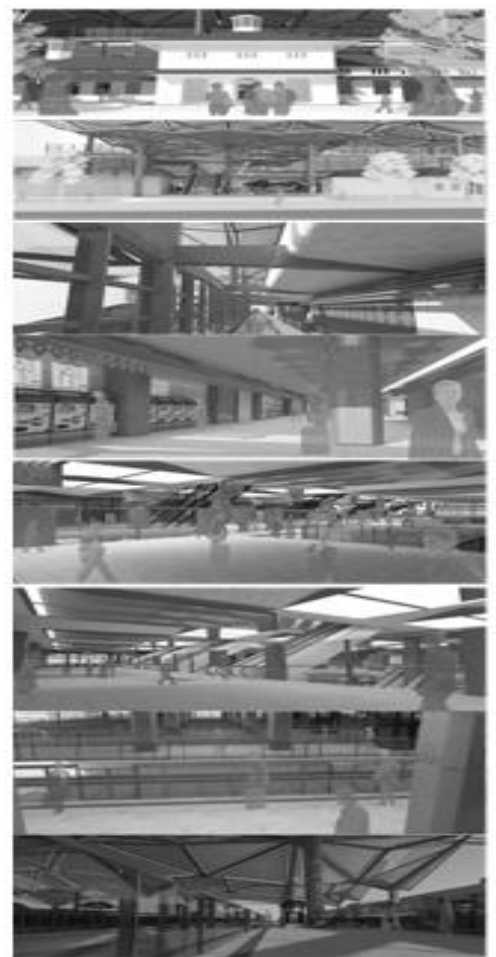

Gambar 7. Skema pada dalam bangunan.

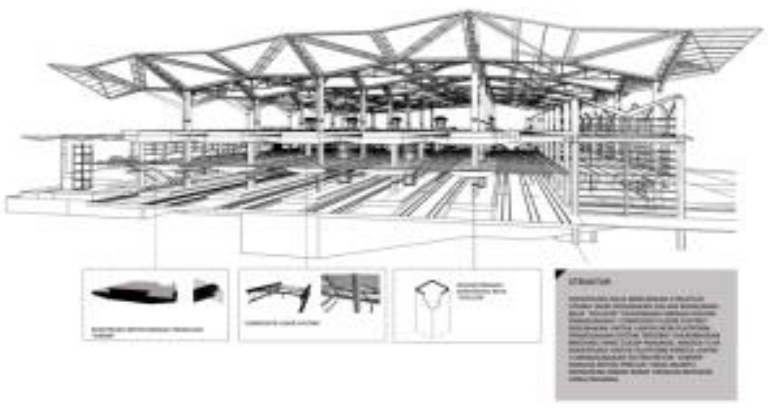

Gambar 8. Struktur Bangunan.

Seorang arsitek harus menjadi sebuah Problem Solver, atau yang dapat menjadi penyelesai masalah, dimana baik masalah arsitektural maupun masalah social [1]. Untuk menyelesaikan sebuah permasalahan maka diperlukan untuk mengetahui apa permasalahan tersebut. Menurutnya, Programming adalah sebuah proses untuk menentukan permasalahan yang akan diselesaikan dengan desain arsitektur. Programming hanya dilakukan pada saat tahap analisa permasalahan yang akan menjadi tujuan dari respon Arsitektural.

Diagrammatic atau Diagram Process, atau metoda desain menggunakan diagram dalam menciptakan sebuah desain Arsitektur. Diagram Process adalah sebuah strategi desain arsitektur yang mendefinisikan kembali hubungan antarbentuk dan ruang [2]. Diagram process adalah sebuah proses mendesain yang lebih menggunakan sebuah diagram sebagai prosedur utama dalam menentukan objek desain dibandingkan dengan menggambar. Namun bukan berarti diagram yang menciptakan sebuah bentuk desain, melainkan adalah sebuah "Alat" untuk membantu menciptakan bentuk desain.

Penerapan penggunaan diagram digunakan dalam melakukan pembentukan zonasi pada massa bangunan. Diagram membantu menciptakan lokasi-lokasi ruang yang akan

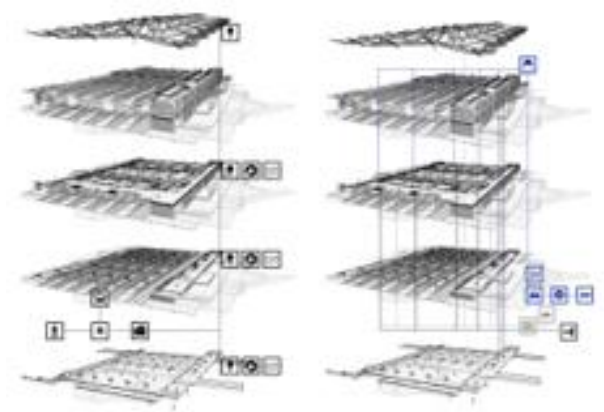

Gambar 9. Utilitas Bangunan.
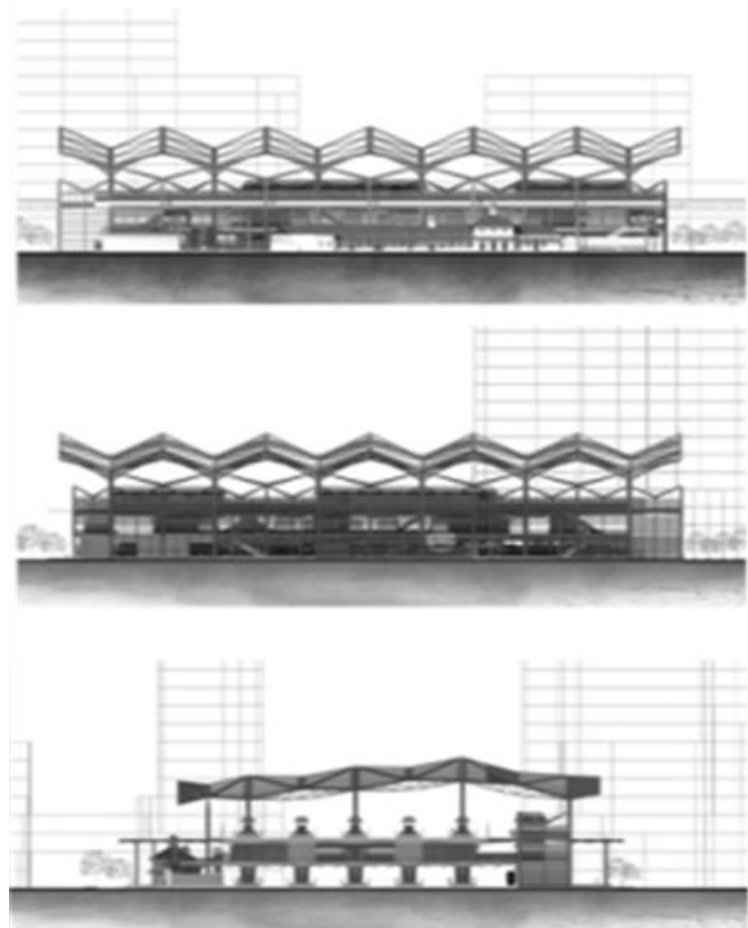

Gambar 10. Tampak Bangunan.

diciptakan dalam massa bangunan. Terdapat beberapa fase dalam menciptakan sebuah bentuk. Yaitu:

1. Ukuran jalur dan peron kereta menjadi acuan utama dalam membentuk sebuah grid dalam bangunan. Titik pada grid akan menjadi sebuah titik kolom dengan harapan mampu mengefisiensikan ruang

2. Grid tesebut diangkat membuat sebuah level baru diatas jalur kereta dan dibawah jalur kereta membuat sebuah lantai 2 dan basement. Lantai 2 berfungsi sebagai lantai yang mengakomodasi aktifitas utama pada stasiun, sedangkan basement sebagai fasilitas parkir, gudang dan lain-lain.

3. Diagram menjadi alat bantu kembali dalam merencanakan zonasi di lantai 2, dalam kasus ini diagram terbentuk dari sebuah analisis potensi lingkungan membentuk ruang-ruang yang dianggap efektif.

4. Setelah posisi ruang dianggap telah efektif. Pembentukan atap mengacu dari beberapa view pada lingkungan. Hal ini dikarenakan peran stasiun yang berfungsi menjadi titik pusat pada kawasan ini. 


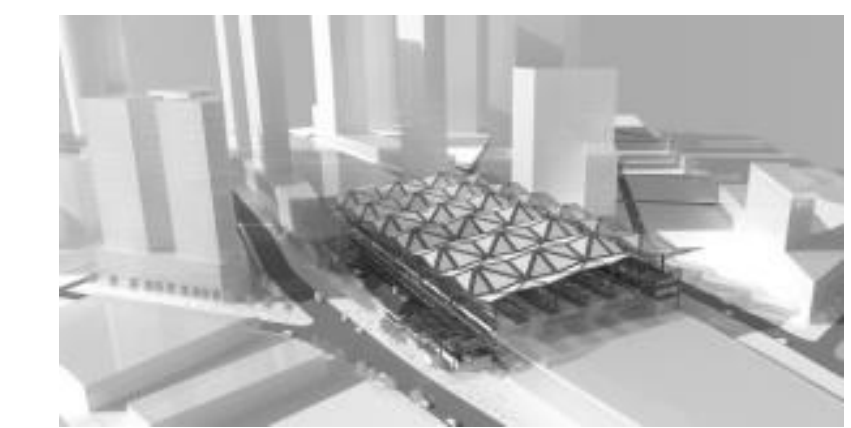

Gambar 11. Bird eye view pada bangunan.

5. Atap pada stasiun terbentuk dari kombinasi atap perisai, atap dianggap mampu menyesuaikan dengan kondisi lingkungan tropis yang memiliki curah hujan tinggi.

\section{HASIL DAN EKSPLORASI}

Berdasarkan dari proses desain tersebut. Maka terdapat hasil desain antara lain:

\section{A. Integrasi Sistem Moda Transportasi}

Desain Stasiun terintegrasi dengan lingkungannya baik secara fisik maupun fungsi. Stasiun yang terletak ditengah kawasan berperan sebagai titik utama pada kawasan yang juga merupakan Area TOD. Akan terdapat penumpang yang melakukan perpindahan moda dari stasiun dan terminal bus, lokasi stasiun yang diapit oleh area komersil dan perkantoran menunjukan perlunya akses langsung yang tidak terganggu. Dari kondisi tersebut maka diperlukan akses langsung yang tidak crossing dengan moda lainnya, sehingga menciptakan fungsi stasiun yang terintegrasi dengan lingkungan. Hal ini sudah tercontoh dari beberapa kota dengan kepadatan yang menyamai Jakarta, seperti pada stasiun-stasiun di kota Tokyo dan Osaka.

\section{B. Hemat Energi}

Penggunaan sistem Passive Cooling dengan Cross Ventilation menjadikan $80 \%$ ruangan pada stasiun bebas menggunakan pendingin ruang. Sehingga mampu meminimalisir penggunaan energy listrik.

Bentuk dan struktur atap yang mengikuti bentuk atap-atap pada iklim tropis juga mampu berperan untuk mengalirkan air hujan yang akan disimpan didalam tandon. Skylight pada atap bangunan memungkinkan cahaya matahari mampu menerangi ruangan didalamnya pada siang hari.

\section{Pengolahan Limbah}

Penggunaan Shaft untuk membuang sampah mengurangi staff sampah, sehingga mengurangi energy yang terbuang. Sampah yang terkumpul didasar secara otomatis terpisah menjadi sampah organic dan non organic. Untuk limbah air bekas Wastafel dapat didaur ulang untuk dipakai kembali sebagaiair untukmenyiram tanaman.

\section{Pemilihan Material}

Penggunaan Material yang tergolong kedalam jenis Prefabrikasi menjadikan pemasangan material tersebut menghasilkan limbah yang lebih minim dibandingkan dengan bangunan yang dibuat secara non prefabrikasi.

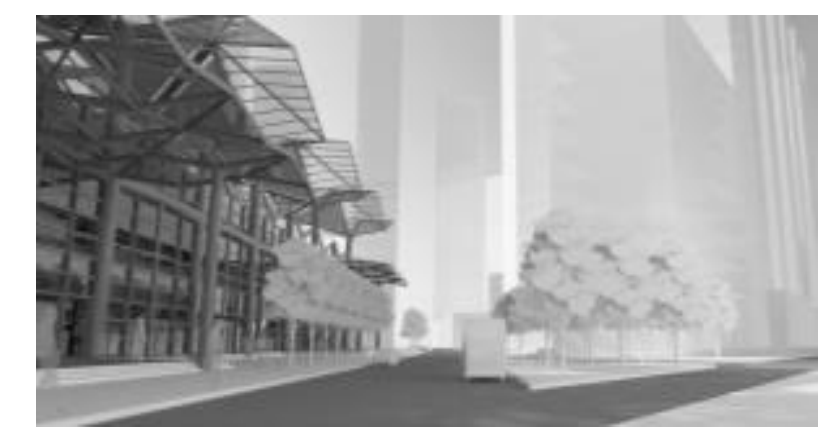

Gambar 12. Suasana lingkungan sekitar.

\section{E. Lokasi}

Dikarenakan stasiun tersebut merupakan sarana Transportasi, serta lokasi stasiun yang merupakan pusat TOD, menjadikan poin tinggi bagi stasiun terhadap aspek ini. Integritas antarmoda yang dimiliki pada stasiun ini juga meningkatkan peran stasiun pada poin ini.

\section{F. Kenyamanan Pengguna}

Pengguna stasiun akan melewati sirkulasi stasiun yang cenderung lurus dan sederhana, menjadikan pola sirkulasi pada stasiun mudah untuk dipahami.

Dengan menggunakan sistem shaft pada pembuangan sampah menjadikan tidak adanya crossing antara sirkulasi sampah dan sirkulasi penumpang. Menjadikan kebersihan ruang pada stasiun lebih terjaga.

Penumpang yang akan naik kereta bilamana masuk melalui pintu masuk pada lantai dasar akan menjumpai 2 buah pintu masuk, dimana pada sisi timur stasiun terdapat pitu masuk orisinil pada bangunan cagar budaya.

Setelah melewati sebuah pintu masuk penumpang akan melewati sebuah hall yang membuat sebuah void hingga atap lantai 3. Hall tersebut akan mengantar penumpang untuk menuju lantai 2 untuk melakukan kegiatan ticketing.

Setelah melakukan kegiatan ticketeing penumpang dapat melakukan aktifitas berbelanja ataupun makan dan minum yang terdapat pada area concourse lantai 2 ataupun pada lantai 3 bangunan sisibarat.

Bilamana penumpang ingin menuju ke kereta maka penumpang harus melewati sebuah ruang khusus yang disebut ruang "Antara", di ruang inilah ticket gate berada, ruang ini memiliki fungsi baik sebagai sirkulasi transit antar kereta maupun sebagai penghubung dari kereta menuju ke Concourse Stasiun

\section{KESIMPULAN}

Berdasarkan hasil perencanaan tersebut, maka kesimpulan yang dapat diambil meliputi beberapa poin sebagaiberikut :

1. Konsep perencanaan stasiun Manggarai terinspirasi dari beberapa data-data dan contoh preseden yang dituangkan dalam gambaran konsep stasiun yang modern, yaitu stasiun yang mampu memenuhi kebutuhan pengguna stasiun kereta api di kota metropolitan dan sebagai pusat dari kawasan TOD (Transit Oriented Development) yang akan dikembangkan oleh Pemerintah Provinsi DKI Jakarta.

2. Penggarapan data berperan penting untuk mengetahui keakuratan kondisi pada lingkungan untuk menghasilkan informasi yang diolah menjadi konsep 
desain. Sehingga desain mampu menjawab permasalahan pada konteks.

3. Dalam suatu perencanaan diperlukan metode rancang yang mampu menyelesaikan permasalahan, sebagai problem solving bagi permasalahan konteks tersebut yang dalam kasus ini adalah Stasiun.

4. Pendekatan Green Building diharapkan bagaimana sebuah stasiun mampu menggunakan energi seefisien mungkin dengan meminimalisir penggunaan listrik dan air dengan alternatif penggunaan penghawaan dan pencahayaan alami.

5. Terdapat Potensi yang lebih besar dari pengembangan pendekatan, metode dan konsep yang diberikan.

\section{DAFTAR PUSTAKA}

[1] W. M. Pena and et al, Problem Seeking - an Architectural Programming Primer. New York: John Wiley \& Sons Inc, 2001.

[2] L. B. Silva, The Diagram Process Method: The Design of Architectural form by Peter Eisenman and Rem Koolhaas. 2014. 